\title{
KEEL MEELES: KONTSEPTUAALSEST SEMANTIKAST ${ }^{1}$
}

\author{
Geda Paulsen \\ Eesti Keele Instituut
}

\begin{abstract}
Kokkuvõte. Kontseptuaalne semantika on kognitiivse suunitlusega keeleteaduse haru, mille eesmärgiks on välja töötada teooria keele toimimisest tajusüsteemi osana. Kontseptuaalset semantikat iseloomustab pürgimus erinevate keelega seotud kognitiivsete alasüsteemide ja nendevaheliste seoste võimalikult täpse formaalse analüüsi suunas. Käesolev artikkel annab ülevaate kontseptuaalse semantika peamistest teoreetilistest seisukohtadest ning nende metodoloogilisest väljendusviisist, asetades teooria üldisemasse keeleteaduslikku konteksti. Tutvustan lähemalt soome keeleteadlase Urpo Nikanne kontseptuaalse semantika tierneti mudeli metodoloogiat, mille abil analüüsin eesti ja soome keele neutraalsete liikumisverbide minema ja mennä/lähteä leksikaalset kontseptuaalset struktuuri ning nn sujumiskonstruktsioonide (X läheb hästi/lörri) semantikat.
\end{abstract}

Märksõnad: kontseptuaalne semantika, semantilised kirjelduskihid ja algüksused, argumentstruktuur, minemisverbid, leksikaalne kontseptuaalne analüüs, konstruktsioon

\section{Sissejuhatus}

Käesoleva artikli teemaks on kognitiivse keeleteooria ühe haru, kontseptuaalse semantika hüpoteesid, kesksed eesmärgid ja keelekäsitlus. Puudutan põgusalt ka teooria suhet lähedalseisvate suundumustega (generatiivne, kognitiivne ja konstruktsioonigrammatika). Peatükk 2 tutvustab kontseptuaalse semantika üldteoreetilisi põhimõtteid ning Ray Jackendoffi representatsioonilise modulaarsuse keelemudelit. Metodoloogiliseks lähte-

1 Artikkel on seotud Haridus- ja Teadusministeeriumi sihtfinantsieeritava projektiga SF0050037s10. 
kohaks on Urpo Nikanne tierneti (kihivõrgustiku) mudel ${ }^{2}$, mille keskseid väljendusvahendeid käsitleb alapeatükk 2.2. Vaatluse alla tuleb leksikaalne kontseptuaalne struktuur koos temaatilise kirjelduskihi, tegevuskihi, semantiliste väljade ning ajasuhete kihiga. Tierneti malli lahendusi rakendan soome ja eesti keele minemisverbide mennä/lähteä ning minema leksikaalse struktuuri kirjelduses ning kahe (eba)õnnestumiskonstruktsiooni analüüsis peatükis 3 .

\section{Kontseptuaalse semantika teoreetilised ja metodoloogilised põhimõtted}

\subsection{Teoreetilised lähtekohad}

Mida me teame, kui mõtleme mingile sõnale või väljendile? Kuidas väljendatakse keeles ruumilist, sotsiaalset või emotsioonidega seotud informatsiooni? Missugune süsteem võimaldab meil oma mõtteid väljendada ja üksteise kõnest aru saada? Kuidas seda kirjeldada? Keelelise semantika olemusest ja ehitusest on olemas väga erinevaid arusaamu kuni seisukohani, mis kahtleb tähendusteooria võimalikkuses üleüldse (nagu Fodor 1987 ja Putnam 1988). Käesoleva artikli teemaks on kontseptuaalne semantika ja selle arusaam tähenduse rollist loomuliku keele kirjelduses.

Klassikaline kontseptuaalse semantika teooria põhineb ameerika keeleteadlase Ray Jackendoffi (1972, 1975, 1983, 1990, $1997,2007,2010)$ ideedel $^{3}$ ja on välja kasvanud generatiivse keeleteaduse interpretatiivse semantika harust, mis otsis võimalust kirjeldada semantilist representatsiooni iseseisva süsteemina, mitte süntaktiliste transformatsioonide tuletisena. Chomsky

2 Kasutan teooria kohta edaspidi ingliskeelset nimetust, kuna seda teeb ka Nikanne oma soomekeelsetes töödes (vt nt http://web.abo.fi/fak/hf/fin/ kurssit/KONSEM/modul_1.htm).

3 Termin conceptual semantics oli esimest korda kasutusel Jackendoffi teoses Semantics and Cognition 1983, kuid juba ka tema varasemad tööd pürgisid modulaarse keeleteooria suunas. 
(1986) järgi võib keelt vaadelda I-semantika (internalized language, seotud keelepädevusega) või E-semantika (externalized language, seotud keelekasutusega) kaudu. Kui E-semantika kuulub tõesemantika valdkonda, uurides keele seost reaalmaailmaga, keskendub I-semantika keele ja maailma suhet vahendavatele mentaalsetele representatsioonidele - sellele, kuidas inimmeel liigendab ümbritsevat. Ülaltoodud jaotuse põhjal on kontseptuaalse semantika uurimisobjektiks I-semantika, kuid see ei vähenda E-semantika kaalu keele olemuse uurimisel ${ }^{4}$. Sellest tulenevalt ei kasuta kontseptuaalne semantika referentsi mõistet standardtähenduses, vaid keskendub "konstrueeritud tähendusele" - sellele, kuidas keelekasutaja kutsub maailma nägema (vt Jackendoff 1983, 1991: 10-12).

Kontseptuaalse semantika põhitees on, et sarnaselt süntaksi ja fonoloogiaga moodustab ka keeleline tähendus kognitiivselt järjestatud süsteemi. Teooria üldteoreetiliseks eesmärgiks on jõuda inimkeele ja -meele teooriani, mis ühendaks keele vormi ja tähendusega seotud aspektid psühholoogiliste ja neuroloogiliste teadmistega meele toimimisest. Jackendoff põhjendab keele psühholoogilise reaalsuse olulisust keeleteooria moodustusele juba oma teoses Semantics and Cognition (1983), võttes selle pürgimuse kokku 'kognitiivse tingimusena' (cognitive constraint, samas: 16): peab olema olemas mentaalse representatsiooni tasand, millel keeleline informatsioon ühildub teiste kognitiivsete süsteemide kaudu edasiantava informatsiooniga ${ }^{5}$ nagu nägemine, kuulmine, haistmine või kinesteetiline süsteem.

4 Nikanne (2008: 3) tõdeb, et kuna keeleteaduslikuks uurimismaterjaliks saab olla vaid keelekasutus, toetub ka kontseptuaalne semantika siiski põhiliselt E-semantikale. Kontseptuaalse semantika ühendamisest keelekasutuse ning pragmaatiliste nähtuste uurimisega vt Petrova 2011 ja Paulsen 2011.

5 Filosoofilisest vaatenurgast on terminite representatsioon ja informatsioon kasutamine antud nähtuste kirjeldamisel problemaatiline, eeldades intentsionaalsuse olemasolu, mistõttu on Jackendoff (2002) võtnud kasutusele neutraalsemad terminid cognitive structure ja (strukturalistliku mõiste) making distinctions. Käesolevas artiklis kasutan siiski termineid representatsioon erinevate keeleliste tasandite kohta, mida ei saa tuletada teistest representatsioonidest (nagu süntaks ja fonoloogia) ja informatsioon "andmete" kohta, mida need tasandid väljendavad. 
Üheks generatiivse grammatika uuenduseks keeleteaduses on keele kombinatoorsete omaduste määratlemine formaalse süsteemina. Formaalsel kirjeldusviisil on Jackendoffi (1997: 4) järgi nii eeliseid kui puudusi: see võimaldab tõstatada hüpoteese ja uurida selgesti väljendatult, abstraktselt ja sidusalt nende üldistusjõudu; samas ei peaks "formaalne tehnoloogia" tõkestama arutelu, vaid soodustama teoreetilise analüüsi tulemuste selget ja kompaktset väljendust. Formaalne keelekäsitus kontseptuaalses semantikas erineb generatiivse grammatika formalismist selle poolest, et representatsioone ei käsitleta üksteisest tuletatuna, vaid keele semantilisele struktuurile antakse iseseisva süsteemi staatus. Tähendusstruktuure vaadeldakse osana kontseptuaalsest struktuurist (ingl k conceptual structure), mistõttu langeb ära generatiivses keeleteoorias pikka aega valitsenud keskustelu selle üle, kas semantiline representatsioon on tuletatud süntaktilisest pind- või süvastruktuurist. Siinkohal on oluline märkida, et representatsioonide iseseisvus ei tähenda nende isoleeritust üksteisest; representatsioonidevaheline suhteseos on kontseptuaalse semantika üks peamisi uurimisobjekte.

Representatsioone autonoomsetena määratledes ei saa oletada eri tasandite vahelist kontiinumit ega segada omavahel erinevate representatsioonide algüksusi. Seega võib öelda, et kontseptuaalne semantika esindab (selgepiirilist) klassikalist kategooriakäsitlust ${ }^{6}$, mille kohaselt vaadeldav entiteet kas kuulub mingisse kategooriasse või mitte ning on määratletud tarvilike ja piisavate tunnuste abil (klassikalistest ja prototüübipõhistest kategooriakäsitlustest vt Taylor 1989). Keeleliste representatsioonide klassikaline kategooriakäsitlus eristab kontseptuaalset semantikat näiteks kognitiivsest grammatikast, mis vaatleb keelekategooriaid osana (samast) kontiinumist, esindades nii prototüübipõhist teooriat. Näiteks iseloomustab Langacker (vt 1991:116-120) keele ehitust tavakohaseks muutunud keelelistest üksustest koosneva liigendatud loendina, kus fonoloogiline ja semantiline kese moodustavad kahepooluselise kontiinumi

6 Prototüübipõhistest kategooriatest kontseptuaalse semantika vaatenurgast vt Paulsen 2011. 
sümboolses keskmes (symbolic space). Vorm ja tähendus on Langackeri (1987: 54) järgi seotud sümbolisatsiooni, st sissejuurdunud semantilise ja fonoloogilise struktuuri ühenduse kaudu; grammatilised moodulid nagu leksikon, morfoloogia ja süntaks on kaotatud ja asendatud sümboolsete struktuuridega. Kontseptuaalne semantika erineb kognitiivsest grammatikast just selle poolest, et mõistab meele esitusi modulaarsena ehk iseseisvate alasüsteemidena toimivana, samal ajal kui kognitiivses grammatikas käsitletakse inimtunnetust ühtse tervikuna ning ka keeleliste kategooriate vahelisi erinevusi nähakse astmelistena.

Keele vormi- ja tähenduskomponendi staatuse võrdsustamine on seotud avastustega neuroteadustes, mis toetavad oletust, et kognitiivsetel representatsioonidel on võime aktiveeruda keelelise informatsiooni töötlemisel paralleelselt ${ }^{7}$. Kontseptuaalne semantika hülgab niisiis generatiivsele grammatikale omase süntaksikesksuse - lauseehituse seaduspärasused ei ole iseenesest fundamentaalsemad kui teised keele koostisosad ja kontseptuaalne struktuur ei ole kodeeritud samade põhimõtete alusel kui süntaks. See vabastab süntaksi liigsest abstraktsusest ja ka komplekssusest, mis on paratamatu, kui oletada, et semantilised nähtused on tuletatud lauseehitusest. Lause või sõna tõlgendamisel tehakse kontseptuaalses semantikas kindlaks kolme põhikomponendi ehk semantilise, fonoloogilise ja süntaktilise osise struktuuriline vastavus. (Vt Jackendoff 1997: 15-18.) Kontseptuaalse semantika nn kolmeosaline mudel on püsinud Jackendoffi uurimustes suhteliselt muutumatuna alates põhiteostest Semantics and Cognition (1983) ja Semantic structures

7 Vastupidiselt seriaalse juurdepääsu mudelile (serial access model, vt Forster 1976), kus sõna töötlemisprotsessi kirjeldatakse selle võimalike variantide järjestikuse otsingu kaudu, esitab paralleelse juurdepääsu mudel (parallel access model), et sõna mõistmisel aktiveeruvad selle potentsiaalsed kandidaadid üheaegselt. Valikul saab määravaks see leksikaalne üksus, millel on stiimuliga kõige rohkem ühiseid tunnuseid. Töömällu jõudnud fonoloogiline sõne aktiveerib niisiis sellega seostuvad semantilised struktuurid sõltumata konkreetsest kontekstist ning need struktuurid jäävad mõneks ajaks töömällu aktiivseks. (Paralleelse juurdepääsu mudeli kohta vt Swinney 1979 ja Tanenhaus jt 1979.) 
(1990) (hiljem määratleb Jackendoff (1997) oma mudelit laiemalt 'representatsioonilise modulaarsuse' kui inimmeele struktuuri üldise omadusena). Jackendoffi mudelit võib kokkuvõtvalt kujutada nagu joonisel 1 (vt nt Jackendoff 1990: 16-18, 1997: 38 ja Nikanne $2002^{8}$ ):

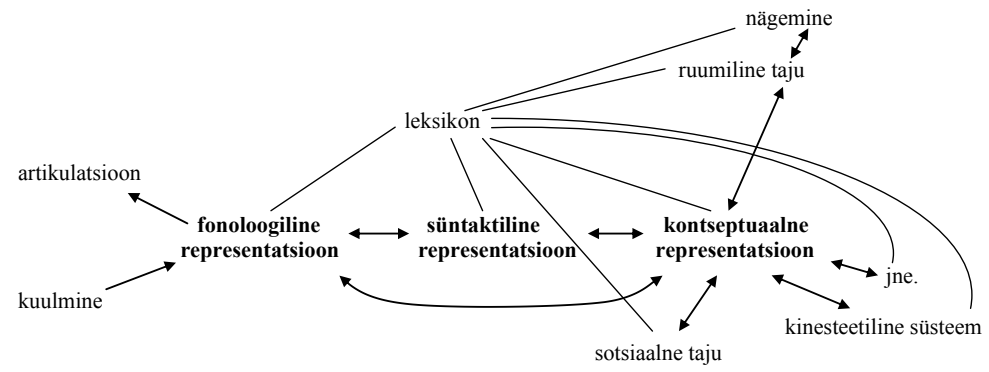

Joonis 1. Jackendoffi kolmeosaline keelemudel.

Joonisel 1 kujutatud kahesuunalised nooled representatsioonide vahel esitavad vastavusseoseid - näiteks semantiliste argumentide seost süntaktiliste argumentidega. Representatsioonisiseste primitiivide ehk kirjelduses kasutavate elementaarüksuste ehituse ja omavaheliste seoste määratlemise kõrval on representatsioonidevahelisi kombinatsioone määravatel reeglitel kontseptuaalses semantikas keskne osa. Sõltumatute representatsioonide vaheline seos põhineb vastavussuhete süsteemil (linking system), mis tähendab ühe representatsiooni mingi osa vastavust teise representatsiooni mingile osale. Siinkohal on oluline märkida, et vastavussuhteid ei mõisteta kontseptuaalses semantikas üks-ühele suhtena: ühe representatsiooni element võib olla seotud ühe, mitme või mitte ühegi teise representatsiooni elemendiga. Ka võib vastavussuhteid olla erinevat tüüpi: vastavus-, sõltuvus- või moodustussuhe (Petrova 2011: 113-114). Leksikonil on ülaltoodud mudelis "ühendussüsteemi" ehk liidese roll: see on (püsimällu salvestatud) assotsiatsioonide ja erinevate representatsioonide fragmentide kogum. Seetõttu pole vastupidiselt peavoolu generatiivse keeleteaduse oletusele lekseemide rolliks olla

8 http://web.abo.fi/fak/hf/fin/kurssit/KONSEM/modul_4.htm (27.03.2012) 
lihtsalt „sisestatud” süntaktilisse struktuuri, vaid Jackendoffi (vt nt 2002:131) sõnul toimivad sõnad ühendusseoste (interface rules) kandjatena süntaktiliste moodustajate ning fonoloogilise ja kontseptuaalse struktuuri vahel.

\subsection{Kontseptuaalne struktuur ja selle analüüs. Tier- neti mudel}

Termin 'mõiste' (concept) tähistab kontseptuaalses semantikas mentaalset esitust, mis toimib keelelise väljendi tähenduskomponendina (Jackendoff 1990: 11). Tähendus on kontseptuaalses semantikas kombinatoorne süsteem ja kontseptuaalne struktuur koosneb iseseisvatest primitiivsetest üksustest. Kontseptuaalse semantika kompositsionaalse struktuuri ülesehitus on analoogiline autosegmentaalse fonoloogia põhimõtetega: foneem on tunnuste põhjal jaotatav väiksemateks osakesteks ning fonoloogiline esitus ühendab erinevate kirjelduskihtide (tier) informatsiooni, nagu meloodia, toon, rõhk (Liberman, Prince 1977, Clements 1985). Ka mingi sõna kontseptuaalse struktuuri analüüsis ei käsitleta kontseptuaalseid üksusi eraldatult, st sõnad ei väljenda ühte kindlat mõistelist algüksust, vaid nende kombinatsioone (vt. Jackendoff 1991: 12).

Kontseptuaalse struktuuri analüüs kirjeldab ontoloogiliste kategooriate (Asi, Omadus, Sündmus, Seisund, Teekond, Aeg, Suund jne) realiseerumist funktsioonide ja argumentidena - iga argument on mingi põhikategooria kontseptuaalne moodustaja ja funktsioonid määratlevad kontseptuaalsete argumentide ehk moodustajate vahelisi suhteid ${ }^{9}$ (vt Jackendoff 1990: 23). Nikanne (2000: 80) jaotab kategooriad lihtsateks kategooriateks, mis esinevad põhiliselt argumendi positsioonis (nagu Asi, Omadus, Kogus) ja kompleksseteks kategooriateks, mis vastavad situatsioonist-

9 Käesolevas artiklis vaatlen lähemalt predikaatide ehk nn komplekssete kontseptuaalsete kategooriate analüüsi; kontseptuaalses semantikas on uuritud ka nimisõnafraaside tähendusosi kvaalistruktuuride näol (vt Jackendoff 1991, 2002), seda pole aga piiratud mahu tõttu võimalik siinkohal käsitleda. 
ruktuure väljendavatele funktsiooni-argumendi ühenditele (nagu Sündmus, Seisund, Teekond).

Kontseptuaalse struktuuri kese on terviksituatsiooni liigendav temaatiline kirjelduskiht (thematic tier), mis väljendab põhjustamist, (abstraktset või konkreetset) muutust või seisundit, muutuse suunda, asukohta jne. (Jackendoff 1983). Temaatilise kirjelduskihi tuumaks on sündmusstruktuuri kujutavad temaatilised funktsioonid, loetlen siinkohal mõned neist (vt Nikanne 2002, 2008):

AT, IN, ON, jne asukohafunktsioonid, viitavad erinevat laadi suhetele asukoha ja viiteobjekti vahel (nt laual, järves).

TO, TOWARD, teekonnafunktsioonid, mis osutavad teekonna ja FROM, AWAY- viiteobjekti vahelistele suhetele (Tartuni, tööst). FROM, VIA

GO osutab teema suhtes toimuvat muutust seoses (konkreetse või abstraktse) teekonnaga (vesi voolab renni).

BE viitab teema ja (konkreetse või abstraktse) asukoha suhtes staatilisele situatsioonile (tüüpiliselt väljendub verbi olema abil).

STAY viitab teema ja selle asukoha suhtes staatilisele, kuid mittepüsivale situatsioonile (jääma).

CAUSE osutab põhjustaja ja põhjustatud situatsiooni vahelist kausatiivset seost (maalima, viskama).

INCH inhoatiivsuse ehk seisundimuutuse funktsioon, väljendab oma otseses mõjualas toimuva situatsiooni algamist (hakkama).

Illustreerimaks lause temaatilise kirjelduskihi analüüsi, toon konkreetse näite. Jackendoffi (1983, 1990) mudelis kirjeldatakse lause Jüri läks sööklasse süntaktilist argumentstruktuuri nagu $(1)^{10}$

10 Kohamääruse määratlus prepositsioonifraasina lauses (1) järgib kohakäändeanalüüsi fonoloogiliselt tühja prepositsioonifraasina (vt Nikanne 1990: 76-86). 
ja vastavat kontseptuaalset struktuuri nagu (2). Analoogselt süntaktilise struktuuri kirjeldusega tähistavad nurksulud analüüsis (2) kontseptuaalseid moodustajaid: iga moodustaja kuulub kontseptuaalsesse põhikategooriasse (Asi, Sündmus jne) ja suurtähtedega märgitud elemendid määratlevad kindlat mõistelist sisu (argumendid JÜRI ja SÖÖKLA ning funktsioonid GO, TO ja IN). Temaatiline funktsioon GO on kahekohaline, ühendades teema (situatsiooni osalejaroll, mille asukohta, seisundit või liikumist lause väljendab näites (2) JÜRI) ja selle liikumise mingisse sihtpunkti terviksündmuseks.

(1) $\left[_{S}\left[_{\mathrm{NP}}\right.\right.$ Jüri $]\left[_{\mathrm{VP}}\left[{ }_{\mathrm{V}}\right.\right.$ läks $]\left[_{\mathrm{PP}}\left[_{\mathrm{NP}}\right.\right.$ sööklasse $\left.\left.\left.]\right]\right]\right]$

(2) $\left[_{\text {Sündmus }} \mathrm{GO}\left(\left[_{\text {Asi }} \mathrm{JÜRI}\right],\left[_{\text {Teekond }} \mathrm{TO}\left(\left[_{\text {Asukoht }} \mathrm{IN}\left(\left[_{\text {Asi }}\right.\right.\right.\right.\right.\right.\right.$ SÖÖKLA $\left.\left.\left.\left.\left.\left.]\right)\right]\right)\right]\right)\right]$

Nikanne (1990, 1995, 1997a, 1997b, 2002, 2005, 2008) kontseptuaalse semantika tierneti mudelis ${ }^{11}$ põhineb grammatiliselt reeglipärane kontseptuaalne struktuur kindlatel valikut (valentsi) määravatel seaduspäradel - kui Jackendoffi kontseptuaalse struktuuri analüüs põhineb moodustajasuhete kujutamisel, siis Nikanne versioon peegeldab elementidevahelisi sõltuvussuheteid. Nikanne väidab, et semantiliste funktsioonide ja argumentide omavahelise kombinatsiooni määrab kindel seaduspära ning semantilised argumendid järjestuvad temaatilises struktuuris vööndite (zone) ja kirjelduskihtide (tier) kaupa. Vööndid määravad grammatiliselt reeglipärase kontseptuaalse

11 Modulaarsuse mõiste erinevates teooriates varieerub moodulitele omistatud informatsiooni ulatuse ja jagunemise osas. Kui Fodori (1983) modulaarses teoorias on keel üks suur moodul teiste inimmeele kognitiivsete võimete hulgas, Jackendoffi representatsionaalse modulaarsuse (1997) teoorias on oletatud kolm keelega seotud keskmoodulit, jaotab Nikanne (1990 jt) tierneti mudel keskmoodulid väiksemateks osadeks. Mikromodulaarne tierneti teooria võimaldab vaadelda tasandite (kihtide) vahelisi ühendusi otsesemalt ning kirjeldada neid ühendavaid tugevamaid ja nõrgemaid sidemeid, viies modulaarsuse põhimõtted lähemale konnektsionismile ehk inimaju talitlust jäljendada püüdvatele (neurovõrgustike funktsioneerimisel põhinevatele) ideedele. 
struktuuri, mille järgi temaatilised funktsioonid paigutuvad ja valivad enda ümber teisi elemente. Temaatilise kirjelduskihi funktsioonid nende potentsiaalsete argumentide temaatiliste (ehk semantiliste) rollidega on esitatud vööndikuuluvuse kaupa Tabelis 1 (vt Nikanne 1997b: 83):

Tabel 1. Vööndid ja temaatilised funktsioonid tierneti mudelis.

\begin{tabular}{l|l|l} 
VÖÖND 3 & VÖÖND 2 & VÖÖND 1 \\
Kausatiivne vöönd & Temaatiline vöönd & Asukohavöönd \\
\hline CAUSE & GO & AT, ON, IN, UNDER... \\
LET & BE & (asukohafunktsioonid) \\
INCH & STAY & TO, TOWARD, FROM, \\
& EXT & VIA, AWAY FROM... \\
& (teekonnafunktsioonid) \\
& MOVE & Temaatiline roll: \\
\hline $\begin{array}{l}\text { Temaatiline roll: } \\
\text { agent }\end{array}$ & $\begin{array}{l}\text { Temaatiline roll: viite- } \\
\text { objekt (asukoht, lähte- } \\
\text { koht, sihtkoht, teekond, } \\
\text { vastuvõtja jne) }\end{array}$
\end{tabular}

Nikanne (1990 ja hiljem) analüüsis moodustab reeglipärase kontseptuaalse struktuuri aluseks olev funktsioonide jada funktsiooniketi (f-keti), mille kombinatsiooniprintsiibid võtab kokku f-ketireegel (3). Valemis viitab number funktsiooni (f) järel kindlale vööndile (üks, kaks või kolm), nool tähistab valikut ja tärn (*) sümboli järel tähendab, et antud vööndi funktsioone võib f-ketis olla üks, rohkem kui üks või mitte ühtegi. Kuna reeglipärane kontseptuaalne struktuur nõuab ühe ja ainult ühe 2. vööndi funktsiooni olemasolu ning 1. ja 3. vööndi funktsioonide arv varieerub nullist mitmeni, võib öelda, et vöönd 2 moodustab temaatilise kirjelduskihi keskme ${ }^{12}$.

12 Näiteks võib lauses olla rohkem kui üks kausatiivne suhe (Mari lasi Jüril saata lapsed poodi) või ka mitu asukohafunktsiooni (Jüri sõitis Tartust Viini Riia kaudu); temaatilise relatsioonita või mitut f2 sisaldav lause aga ei ole grammatiliselt reeglipärane (*Mari Tartusse; *Mari jookseb loeb Tartus). 
(3) f-ketireegel: $\mathrm{f3}^{*} \rightarrow \mathrm{f} 2 \rightarrow \mathrm{f} 1^{*}$

Tierneti teooriale on iseloomulik, et temaatilisi rolle ei käsitleta hierarhilise loendina, vaid rollihierarhia tuleneb f-keti printsiibist, mis määrab funktsioonide ja nende argumentide vahelisi sõltuvussuhteid (Nikanne 1997b). Lause kontseptuaalset struktuuri analüüsides sisestatakse f-ketti konkreetne funktsioon ning iga funktsiooni poolt valitud temaatiline argument. Valikut tähistavad kirjelduses nooled: näiteks lause (4) analüüsis valib funktsioon CAUSE argumendi MARI ja lisaks funktsiooni GO (märgistusviisist vt Nikanne 1990 ja 2002):

(4) Mari saadab Jürile kirja.

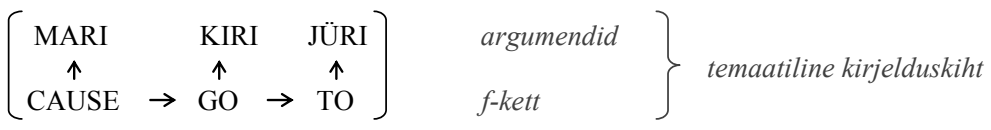

Kontseptuaalse semantika temaatiliste rollide tõlgendus on märkimisväärne selle poolest, et kontseptuaalne argument ei pea olema süntaksis väljendatud ja teisalt võib ka implitsiitne argument olla rohkem kui ühes argumendi positsioonis. Ühel süntaktilisel argumendil võib niisiis kontseptuaalses struktuuris olla mitu semantilist rolli, nagu näites (5). Järgin analüüsis Jackendoffi (1990: 63) esitatud formalismi kontseptuaalse struktuuri seesmise seotuse (binding) tähistamiseks, mille kohaselt samaosutuslikud argumendid ühendatakse kreeka tähtede abil; vt refleksiivse verbi riietuma analüüs (5), kus siduv argument MARI saab ülaindeksi $\alpha$ ja seotud argument on märgitud tavasuuruses $\alpha$-ga. Kontseptuaalsest struktuurist väljuvad seosed ehk lauseehituse ja kontseptuaalse struktuuri vastavussuhted on analüüsis (5) märgitud numbritest alaindeksite abil (vt Nikanne 2000): näiteks alaindeksiga 2 märgitud süntaktiline subjekt Mari vastab temaatilisele põhjustaja-argumendile MARI.

(5) Mari ${ }_{2}$ riietub mantli $_{3} \mathrm{Sse}_{4}$.

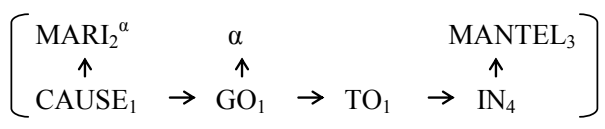


Implitsiitne argument ehk süntaktilises struktuuris märkimata semantiline argument on Nikanne (1990) formalismis tähistatud ülaindeksiga I. Näide implitsiitsest argumendist on VÕI analüüsis (6), väljendades verbi määrima implitsiitset teemat MÄ̈̈REI.

(6) Mari ${ }_{2}$ määrib võid $_{3}$ kukli $_{4} \mathrm{le}_{5}$.

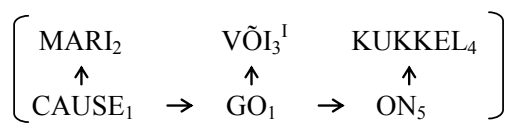

Siiani oleme keskendunud kontseptuaalse struktuuri temaatilisele kirjelduskihile, mis väljendab keelelise propositsiooni situatsioonistruktuuri (muutus, põhjustamine, seisund jne). Kontseptuaalses struktuuris esitatakse aktiivsete ja passiivsete osaliste analüüs eraldi kihil, tegevuskihil ${ }^{13}$ (action tier, vt Jackendoff 1990 ja Nikanne 1990, 1995). Tegevuskiht väljendab situatsiooni osalejatevahelisi domineerimissuhteid ning aktiivsust ja passiivsust, rollideks toimija (actor) ja patsient (undergoer). Tegevuskiht moodustab omaette tegevusketi (act-chain), mille funktsioonideks on AC (toimija) ja UN (patsient) (Nikanne 1995).

Osavõtjasuhete kirjeldusele lisab situatsiooni kognitiivse tausta semantiliste väljade kiht (semantic fields, Jackendoff 1990 ja Nikanne 1990). Lokalismihüpoteesi järgi on ruumilisi seoseid esitavatest mõistetest võimalik tuletada erinevat tüüpi väljendeid (vt nt Gruber 1965), mis on ka üks kontseptuaalse semantika juhtmõtteid (Jackendoff (1983) sõnastab selle nn 'temaatiliste suhete hüpoteesina'). Ruumisuhete eristaatusele või markeerimatusele osutab muuhulgas ruumisuhteid väljenda-

13 Aktiivse ja passiivse osalejarolli eraldas Jackendoff (1972) teistest semantilistest rollidest algselt kriitikana Fillmore'i (1968) idee vastu, et iga NP võib saada ainult ühe semantilise rolli. Kui Jackendoffi teoorias on tegevuskihil süntaktiliste positsioonide seisukohast esmane staatus (vt 1990), siis Nikanne (1995) väitel tegevuskiht süntaktiliste argumentide määramist ei mõjuta. Toimija ja patsiendi eraldamist omaette tasandile pooldavad ka Foley ja Van Valin (1984). 
vate keeleliste vahendite kasutamine abstraktsete mõistete edasiandmisel, nagu liikumisverbi minema kasutus osutab:

$\begin{array}{ll}\text { Mari läks majja. } & \text { (ruumiline) } \\ \text { Esikoht läks Marile. } & \text { (possessiivne) } \\ \text { Mari läks hulluks. } & \text { (iseloomustav) }\end{array}$

Situatsiooni tegevuslaadi, selle kulgu ajas, kujutatakse kontseptuaalses semantikas ajasuhete kihil (temporal tier, vt Jackendoff 1990, Nikanne 1990, 1997b ja 2008 ning Pörn 2004). Ajasuhete kihi algüksused on P (point, punkt ajas) ja R (region, piirkond ajas), mis annavad järgmisi kombinatsioone: $\mathrm{P}, \mathrm{R}, \mathrm{PR}$, RP, PRP ja RPR. Nikanne (1990: 177-178) rõhutab, et kui situatsioonis sisaldub R, on sel suunatud ajaline kestus; P tähendab, et situatsioonil ei ole ajalist kestust. $\mathrm{R}$ viitab seega situatsiooni protsessuaalsusele. Kuna $\mathrm{P}$ on nulldimensionaalne entiteet, võib seda visualiseerida punktina; $\mathrm{R}$ on ühedimensionaalne ja seda võib väljendada joone abil:

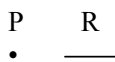

Lause Mari saatis Jürile kirja erinevate kontseptuaalse struktuuri kihtide analüüsis (7) on kaks temporaalset sündmust, kuna üldsituatsiooni kuulub ka põhjustamine, väljendatud funktsiooni CAUSE abil. Põhjustamise ehk kolmanda vööndi semantiline väli on selles lauses füüsiline (Mari saadab kirja teele) ja tuumvööndite ${ }^{14}$ ehk vööndite kaks ja üks semantiline väli on possessiivne (kiri läheb Jüri omandusse). Argumendid MARI ja JÜRI saavad lisaks temaatilise kihi rollidele (vastavalt põhjustaja ja sihtpunkt) tegevuskihi rollid (toimija $\mathrm{AC}$ ja patsient UN). Lause ajastruktuuri kuulub kaks ajalist järgnevust: alguspunkti sisaldavale kestusele järgneb lõpp-punktiga ajapiirkond ( $\mathrm{Z}$ tähistab analüüsis vööndit ja number väljendab vööndi numbrit; vrd tabel 1).

14 Nikanne (2002) analüüsis sulandub asukohavööndi (vöönd 1) ja temaatilise vööndi (vöönd 2) semantiline väli lahutamatuks väljaks, mis on ka üheks põhjuseks käsitleda neid vööndeid tuumvöönditena. 


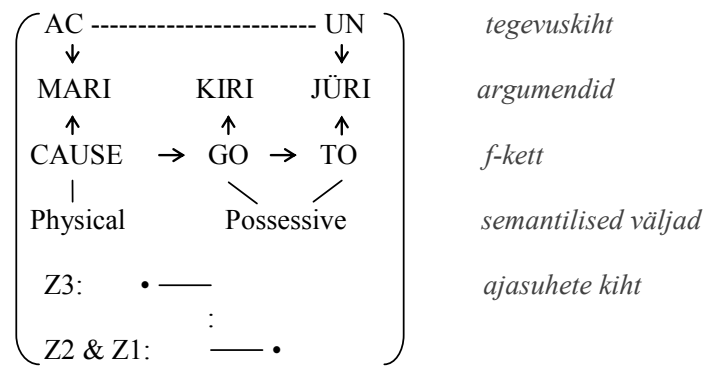

Ajasuhete kihi struktuuri võib täpsustada algüksuste määratlemisest kaugemale. Pörn $(2004,2008)$ eraldab komplekssete ajastruktuuride puhul üksteisest alguspunkti ja lõpp-punkti tähistega $\mathrm{P}_{\mathrm{S}}$ (starting point) ja $\mathrm{P}_{\mathrm{f}}$ (final point); struktuuri (7) ajasuhteid võiks niisiis kirjeldada ka kombinatsioonide $\mathrm{P}_{\mathrm{S}} \mathrm{R}$ ja $\mathrm{RP}_{\mathrm{F}}$ kaudu. Põhjustamisega on seotud erinevat tüüpi ajalised suhted, sõltuvalt sellest, kas põhjustav situatsioon ehk 3. vööndit hõlmav piirkond kestab sama kaua kui põhjustatud situatsioon (vööndid 2-1) või hõlmab ajaliselt ainult põhjustava situatsiooni. Esimesel juhul on tegu kaasava põhjustamisega (entrainment causation, nt Jaan kandis laua tuppa) ja teisel juhul käivitava põhjustamisega (launching causation, nt Jaan viskas kirve jõkke) (vt Jackendoff 1990, Nikanne 1990, Pörn 2004, 2008). Näite (7) puhul on tegemist käivitava põhjustamisega, mistõttu ühendan ajastruktuurid analüüsis kaksikpunktiga (tähistusest vt Nikanne 1990: 188-190).

\section{Leksikaalsed ja konstruktsioonipõhised vastavus- suhted}

Tähenduse ja vormi omavahelisel seosel on keeles erinevat tüüpi väljendusi, näiteks leksikaalne, morfoloogiline ja konstruktsioonipõhine vastavussuhete süsteem. Konstruktsiooni määratlus kontseptuaalses semantikas ${ }^{15}$ ühtib üldjoontes konst-

15 Erinevalt Jackendoffist (1997) käsitleb Nikanne (2002, 2005) konstruktsioone eraldi moodulina, mitte leksikoni osana ning argumenteerib reeglipärase (default) vastavussuhete süsteemi ebareeglipärasest lahushoidmise poolt. 
ruktsioonigrammatika nägemusega konstruktsioonist kui sõnast laiemast struktuurist, mille kirjeldamisel tuleb viidata tervikstruktuurile, mitte pelgalt selle osadele ja nende reeglipärasele kombinatsioonile (Nikanne 2002, 2005, vrd Goldberg 1995, Kay, Fillmore 1999). Vaatlen järgnevas leksikaalsete ja konstruktsioonipõhiste vastavussuhete seaduspärasuste omadusi eesti ja soome keele minemisverbide näitel.

Jackendoffi (1983: 56) väitel ei ole keelespetsiifilist semantilist representatsiooni vaja, vaid piisab universaalse kontseptuaalse struktuuri oletusest; keeltevahelised erinevused tulenevad üldiste kombinatsiooni- ja vastavusreeglite erinevusest. Nagu fonoloogiliste tunnuste osaski, ei kasuta ükski loomulik keel kõiki võimalikke kontseptuaalseid algüksusi, vaid nende kindlaid kombinatsioone. Näiteks minemisverbide semantikasse kuulub suunalisus ja nende kontseptuaalse struktuuri tuumaks on suunafunktsioon GO koos asukoha- või teekonnafunktsiooniga. Eesti keele neutraalset liikumist kirjeldavale verbile minema vastavad soome keeles verbid mennä ja lähteä. Nende üldkirjelduses võib teekonna funktsiooni jätta täpsustamata, kuna siin võib fokuseerida nii teekonna lähtekohale (FROM) kui ka sihtkohale (TO):

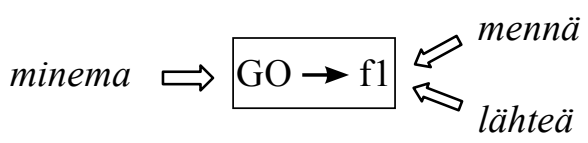

Eesti ja soome minemisverbide leksikaalne analüüs osutab semantilistele (distributsiooni)erinevustele. Soome keele mennä-verbi põhitähenduseks on Suomen kielen perussanakirja järgi liikumine mingisse sihtpunkti. Selle verbi leksikaalset kirjet võib seega väljendada nagu (8). Funktsiooni TO argument on selles analüüsis implitsiitne sihtkoht. Verbi põhiliseks tähendusalaks võib lugeda teema siirdumist ruumilises semantilises väljas, kuid kuna see pole kaugeltki ainuke (verbide mennä ja lähteä korpuspõhisest võrdlusest ja semantiliste väljade analüüsist vt Pällin 2011), jätan semantilise välja siinkohal määratlemata. 


$$
\begin{aligned}
& \text { /mennä/ } \\
& \text { V } \\
& \left(\begin{array}{cc}
{\left[\begin{array}{cc}
{ }_{\uparrow} & {[} \\
\uparrow & ]^{\mathrm{I}} \\
\mathrm{GO} \rightarrow & \mathrm{TO}
\end{array}\right]} \\
\mathrm{Z} 2 \& \mathrm{Z} 1: &
\end{array}\right)
\end{aligned}
$$

Verbi lähteä põhitähenduseks annab Suomen kielen perussanakirja 'minema hakkama' või 'lahkuma', teisisõnu fokuseerib verb teekonna lähtepunktile ${ }^{16}$. Kuna 'hakkamine' ja tegevuse alustamine lisavad verbitähendusele inhoatiivsuselemendi, kuulub lähteä leksikaalsesse kontseptuaalsesse struktuuri funktsioon $\mathrm{INCH}^{17}$. Et see pole kohustuslik komponent, väljendavad valikulisust nurksulud funktsiooni ümber:

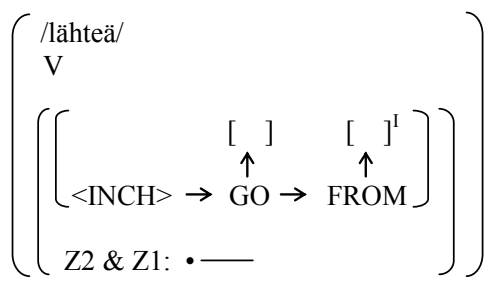

Ka eesti keeles ei ole inhoatiivsus verbi minema kohustuslik tähendusjoon - EKSS annab muutumis- ja hakkamistunnuse tähendusblokile 3 ('lahkuma'), 4 ('kaduma'), 5 ('oma seisundit muutma') ja 6 ('protsessi või tegevust alustama'). Inhoatiivsus on minema-verbile iseloomulik faasiverbikonstruktsioonides (Sahkai 2008). Ka ei saa verbi minema puhul öelda, et see fokuseeriks mingile kindlale teekonna osale - sõltuvalt lausekontekstist on võimalikud nii lähte- kui ka sihtpunkti tähendus kui ka (määratlemata) liikumistegevus. Seetõttu on verbi leksikaalses

16 Lähtepunkti väljendamine on siiski siinkohal ilmselt üldistus, kuna lähteä-verbi võib kasutada ka sihtpunkti sisaldavates lausetes nagu Lähden kaupunkiin 'lähen linna'.

17 Funktsioon INCH on ühekohaline (monadic) funktsioon; ühekohalisus tähendab, et funktsiooni valikualasse kuulub kas parempoolne funktsioon või temaatiline argument. 
kirjelduses (10) määratlemata f1 argumendiks implitsiitne teekond:

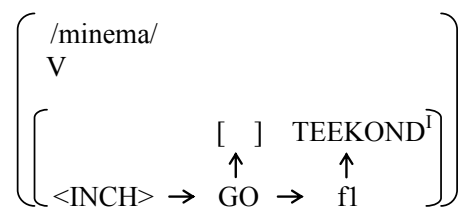

Minema ning mennä/lähteä on kõrge sagedusega verbid, mis väljendavad lisaks ruumilisele liikumisele mitmeid erinevaid tähendustüüpe. Käesolevas artiklis annan väga üldise kirjelduse ühest piltlikust tähendusrühmast kummaski keeles. Need on nn õnnestumis- ja ebaõnnestumiskonstruktsioonid, mis on soome keeles koondunud verbi mennä ümber. Ebaõnnestumisväljendid on seotud olukorra muutust väljendava tähendusega, kus mingi normaalolukord muutub erandlikuks, tavaliselt halvemaks (vt Nykysuomen sanakirja mennä-verbi III tähendusbloki 1. rühm). mennä-verb annab hulgaliselt eri tüüpi ebaõnnestumisväljendeid, millest siinkohal analüüsin sihikäändelist adverbiaali sisaldavat (tüüpiliselt illatiivis, allatiivis või translatiivis) "nurjumiskonstruktsiooni":

(11) Nurjumiskonstruktsioon (Jokin (homma) menee hulinaksi/plörinaksi; vikaan/puihin; pilalle/pakkaselle)

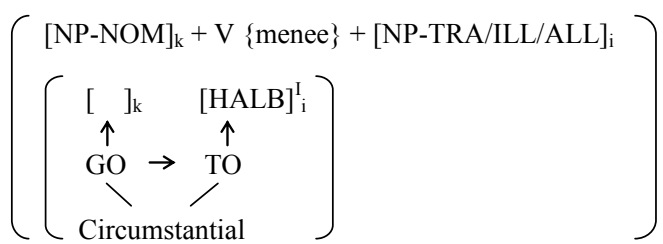

Nurjumiskonstruktsiooni struktuuri kuuluvad minemisverbidele omaselt muutus ja suunalisus, analüüsis väljendatud GO-funktsiooni abil. Sihtkohafunktsiooni TO implitsiitseks argumendiks on määratletud abstraktne omadus HALB. Situatsiooni semantiline väli on seisundiline (circumstantial), mis on seisundimuutuse väli, tähistades olukorra muutust ja tüüpiliselt teema siirdumist mingisse teise olukorda (Jackendoff 1983, 
Nikanne 1990). Ka eesti keeles võib minema-verbi kasutada nurjumiskonstruktsioonis, adverbiaali käändeks on siis tüüpiliselt illatiiv (lörri/untsu minema).

Nii soome mennä kui eesti minema võivad esineda ka konstruktsioonis, mis ei väljenda muutust (mul läheb hästi; minulla menee hyvin) - nimetan seda siinkohal sujumiskonstruktsiooniks (12). Adessiivikäändelise kogejaargumendi valib selles konstruktsioonis funktsioon STAY, mis väljendab selle argumendi püsimist mingis kohas teatud ajaliselt piiratud situatsioonis. Sujumiskonstruktsiooni alastruktuuri semantiline väli on identifitseeriv (identificational, vt Jackendoff 1983: 194), mis väljendab mingi omaduse omistamist teema referendile (implitsiitne OLUKORD konstruktsioonis (12)).

(12) Sujumiskonstruktsioon (X:llä menee lujaa/hyvin/ huonosti; X:l läheb hästi/halvasti)

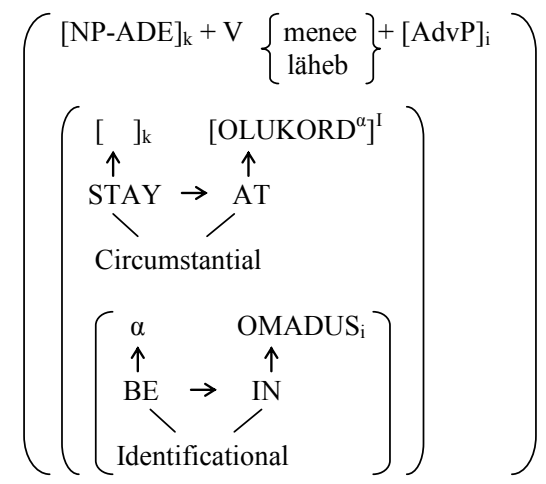

Kirjeldatud konstruktsioonid on niisiis osaliselt tardunud iseloomuga, väljendudes kindlaksmääratud süntaktilises (adessiivkogeja, adverbiaalikääne) ning semantilises (fikseeritud tüüpi argumendid, kindel situatsioonitüüp) struktuuris. Võib küsida, mis on minemisverbide minema ja mennä leksikaalsel tähendusel ning (eba)õnnestumisväljenditel ühist? E-semantika (keele ja maailma vahelise suhte) vaatenurgast on tegemist nähtustega, mis viitavad erinevatele referentidele. I-semantika, mis keskendub kogemuse konstrueerimise viisile, osutab analoogiale 
antud nähtuste skematiseerimisel - nurjumiskonstruktsiooni puhul on selleks teema (piltlik) liikumine ebasoovitavasse sihtpunkti ning sujumiskonstruktsiooni puhul teema püsimine mingis hinnanguliselt positiivses või negatiivses olukorras.

\section{Lõpetuseks}

Käesolevas artiklis olen püüdnud tutvustada kontseptuaalse semantika eesmärke ning teoreetilist ja metodoloogilist lähenemisviisi keele olemuse lahtimõtestamisel. Piiratud mahu tõttu on kirjeldusaparaadist siin käsitletud vaid väike, kuid keskne osa. Kokkuvõtvalt võib öelda, et teoorial on omadusi (täpsusele suunatud väljendusvorm, avatud süsteem), mis annavad võimalusi semantika ja süntaksi vaheliste seaduspärade uurimiseks. Ülal mainitud süsteemi avatus tähendab, et see pole „lõplik": uusi avastusi (näiteks täpsustunud primitiivide näol) on võimalik analüüsi sisse viia ja strukturaalseid komponente muuta. Keeltevahelises võrdluses võib formaalse kujutusviisi eeliseks tuua analüüsi tulemuste eksplitsiitse ja täpsusele pürgiva väljenduse. Kontseptuaalse struktuuri kirjeldusvõrgustik võib tunduda esmakordsel tutvumisel krüptiline, kuid uurimuseesmärke arvestades võimaldab detailne formaalne esitus lahti mõtestada mitmetahulisi tähendusaspekte ning kompleksseid vastavusseoseid, mida keelelised väljendid sisaldavad.

\section{Tänuavaldused}

Tänän Kristi Pällinit soome keele minemisverbide mennä ja lähteä leksikaalseid omadusi puudutavate selgituste eest ning Heete Sahkaid ja Ene Vainikut artikli lõplikku versiooni puudutavate kommentaaride eest. Võlgnen tänu ka toimetajatele märkuste eest, mis parandasid tunduvalt nii artikli loetavust kui ka mõttekäikude loogilisust. 


\author{
Aadress: \\ Geda Paulsen \\ Eesti Keele Instituut \\ Roosikrantsi 6 \\ 10119 Tallinn \\ E-mail:Geda.Paulsen@eki.ee
}

\title{
Kirjandus
}

Chomsky, Noam (1986) Knowledge of language: its nature, origin, and use. New York: Praeger.

Clements, George (1985) "The geometry of phonological features". Phonology Yearbook 2, 223-252.

EKSS = Eesti kirjakeele seletussõnaraamat. Margit Langemets, Mai Tiits, Tiia Valdre, Leidi Veskis, Ülle Viks, Piret Voll, toim. Tallinn: Eesti Keele Sihtasutus. <http://www.eki.ee/dict/ekss/ekss.html>. Vaadatud: 29.03.2012.

Fillmore, Charles J. (1968) "The case for case". In Emmon Bach, Robert T. Harms, eds. Universals in linguistic theory, 1-88. New York: Holt, Rinehart \& Winston.

Fodor, Jerry (1983) The modularity of mind: an essay on faculty psychology. Cambridge, MA: MIT Press.

Fodor, Jerry (1987) Psychosemantics. Cambridge, MA: MIT Press.

Foley, William, A., Robert D. Van Valin (1984) Functional syntax and universal grammar. Cambridge: Cambridge University Press.

Forster, Kenneth I. (1976) "Accessing the mental lexicon". In Edward C. J. Walker, Roger J. Wales, eds. New Approaches to language mechanisms 30, 231-256 Amsterdam: North-Holland.

Goldberg, Adele (1995) Constructions. Chicago: University of Chicago Press.

Gruber, Jeffrey (1965) Studies in lexical relations. Massachusetts Institute of Technology. Department of Modern Languages. Ph.D Thesis: <http:// dspace.mit.edu/handle/1721.1/13010>. Vaadatud: 10.08.2011.

Jackendoff, Ray (1972) Semantic interpretation in generative grammar. Cambridge, MA: MIT Press.

Jackendoff, Ray (1975) "Morphological and semantic regularities in the lexicon". Language 59, 639-671.

Jackendoff, Ray (1983) Semantics and cognition. Cambridge, MA: MIT Press. Jackendoff, Ray (1990) Semantic structures. Cambridge, MA: MIT Press.

Jackendoff, Ray (1991) "Parts and boundaries". Cognition 41, 9-45.

Jackendoff, Ray (1997) The architecture of the language faculty. Cambridge, MA: MIT Press. 
Jackendoff, Ray (2002) Foundations of language: brain, meaning, grammar, evolution. Oxford: Oxford University Press.

Jackendoff, Ray (2007) Language, consciousness, culture: essays on mental structure. Cambridge, MA: MIT Press.

Jackendoff, Ray (2010) Meaning and the lexicon. The parallel architecture 1975-2010. Oxford: Oxford University Press.

Kay, Paul, Charles J. Fillmore (1999) "Grammatical constructions and linguistic generali-zations: The What's $X$ doing $Y$ ? construction”. Language 75, 1-33.

Langacker, Ronald (1987) Foundations of cognitive grammar. Vol 1: Theoretical prerequisites. Stanford, CA: Stanford University Press.

Langacker, Ronald (1991) Concept, image and symbol: the cognitive basis of grammar. Berlin: Mouton de Gruyter.

Liberman, Mark, Alan Prince (1977) "On stress and linguistic rhythm”. Linguistic Inquiry 8, 249-336.

Nikanne, Urpo (1990) Zones and tiers. Helsinki: Suomalaisen Kirjallisuuden Seura.

Nikanne, Urpo (1995) "Action tier formation and argument linking". Studia Linguistica 49, 1-32.

Nikanne, Urpo (1997a) "Locative case adjuncts in Finnish: notes on syntactosemantic interface". Nordic Journal of Linguistics 20, 155-178.

Nikanne, Urpo (1997b) "Lexical conceptual structure and syntactic arguments". SKY Journal of Linguistics 10, 81-118.

Nikanne, Urpo (2000) "Some restrictions in linguistic expressions of spatial movement". In Emile van der Zee, Urpo Nikanne, eds. Cognitive interfaces: constraints on linking cognitive Information, 77-93. New York: Oxford University Press.

Nikanne, Urpo (2002) Kerrokset ja kytkennät. <http://www.abo.fi/fak/fin/ kurssit/KONSEM/>. Vaadatud: 13.10.2012.

Nikanne, Urpo (2005) “Constructions in conceptual semantics”. In Jan-Ola Östman, Mirjam Fried, eds. Construction grammars: cognitive grounding and theoretical extensions, 191-242. Amsterdam: John Benjamins.

Nikanne, Urpo (2008) "Conceptual semantics". In Jan-Ola Östman, Jef Verschueren, Eline Versluys, eds. Handbook of pagmatics, 1-21. Amsterdam: John Benjamins.

Nykysuomen sanakirja I-IV (1996). 14. trükk (1951-1961). Porvoo: WSOY.

Paulsen, Geda (2011) Causation and dominance: a study of Finnish causative verbs expressing social dominance. Åbo: Åbo Akademi University Press. <https://www. doria.fi/handle/10024/67355>. Vaadatud: 13.10.2012.

Petrova, Oksana (2011) Of pearls and pigs: a conceptual-semantic tiernet approach to formal representation of structure and variation of phraseological units. Åbo: Åbo Akademi University Press.

Putnam, Hilary (1988) Representation and reality. Cambridge, MA: MIT Press. 
Pällin, Kristi (2011) Suomen mennä- ja lähteä-verbien korpuspohjainen vertailu konseptuaalisen semantiikan näkökulmasta. Magistritöö. Käsikiri Tallinna Ülikooli eesti keele ja kultuuri instituudis.

Pörn, Michaela (2004) Suomen tunnekausatiiviverbit ja niiden lausemaiset täydennykset. Helsinki: Suomalaisen Kirjallisuuden Seura.

Pörn, Michaela (2008) "Psychophysical and physical causative emotion verbs in Finnish: the temporal structure of causative emotion verb + infinitive 1 - constructions within conceptual semantics". SKY Journal of Linguistics 21, 201-218.

Sahkai, Heete (2008) "Konstruktsioonipõhine keelemudel ja sõnaraamatumudel”. Eesti Rakenduslingvistika Ühingu aastaraamat 4, 177-186.

Suomen kielen perussanakirja (1996), 4. tr. Kotimaisten kielten tutkimuskeskus, Helsinki: Edita.

Swinney, David (1979) "Lexical access during sentence comprehension: (re) consideration of context effects". Journal of Verbal Learning and Verbal Behavior 18, 645-659.

Tanenhaus, Michael, James Leiman, Mark Seidenberg (1979) "Evidence for multiple stages in the processing of ambiguous words in syntactic context". Journal of Verbal Learning and Verbal Behavior 18, 427-440.

Taylor, John R. (1989) Linguistic categorization: prototypes in linguistic theory. Oxford: Clarendon Press.

\begin{abstract}
Geda Paulsen: Language in mind: about conceptual semantics. This paper discusses the framework of conceptual semantics and its methodological solutions for the semantic analysis. The conceptual semantics theory, based on the ideas of Ray Jackendoff, strives for an integration of the psychological reality of linguistic information with other linguistic faculties. The article discusses the central theoretical assumptions and aims of this theory and also gives a brief presentation of the basic methodology of Urpo Nikanne's tiernet model of conceptual semantics. The tiernet technology is the basis for the analysis of the lexical conceptual structure of the Finnish neutral motion verbs mennä 'go' and lähteä 'go from a place' as well as of the Estonian counterpart minema 'go'. Two "(un)success-constructions" in connection with these verbs are also discussed.
\end{abstract}

Keywords: conceptual semantics, semantic tiers and primitives, linking, lexical conceptual analysis, neutral motion verbs, constructions 